\title{
㽞 The Influence of School Headmaster Transformation Leadership and Work Satisfaction on Teachers Organizational Committee
}

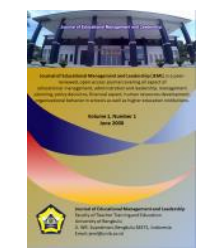

\author{
Iwan Rio Darma Putra Purba ${ }^{1 *}$ and Rohiat Rohiat ${ }^{2}$ \\ ${ }^{1}$ SMKN Regency of Rejang Lebong \\ ${ }^{2}$ Study Program of Educational Administration, University of Bengkulu \\ *Email: jay.89prasetyo@gmail.com
}

DOI: https://doi.org/10.33369/jeml.1.1.22-24

\begin{abstract}
An organization can achieve its objectives as planned if there is a good coordination from various parties in the organization, one of them is an organizational committee that is built individually in it. Based on this statement, the researcher wants to find the influence of transformational leadership and job satisfaction on organizational commitment. The location of this research was State Vocational School in Rejang Lebong Regency. The purpose of this study was to determine how much influence the transformational leadership of school principals and job satisfaction on the organizational commitment of vocational school teachers in Rejang Lebong Regency. This research is expected to be useful for principals and teachers in order to know the critical determinants of the success of the principal's transformational leadership style and job satisfaction with organizational commitment. The method used quantitative with a descriptive approach. This method explained the results of calculations with regression techniques as an analysis tool. The population in this study was 106 teachers with 84 teachers as sample. It showed that, school and job satisfaction were affecting the commitment of the organization of teachers of state vocational schools Rejang Lebong with a coefficient value of 0.706 and an effect of 0.498 or $49.8 \%$ in the form of linearly positive. Based on the results of the study, suggestion is given to the teachers that should increase the organizational commitment.
\end{abstract}

Keywords: Principal transformational leadership, job satisfaction, organizational commitment.

\section{INTRODUCTION}

An organization can achieve its objectives in accordance with what has been planned if there is coordination from various parties in the organization, one of them is an organizational committee that built individually in it (Mullins, 2007; Robbins and Judge, 2006; Waworuntu, 2016). The commitment appear is not only passive loyalty but also involves an active relationship in work organizations that aims to provide all efforts for the success of the organization concerned. The explanation can be interpreted that in the implementation of commitment must be active loyalty, so that, the work organization climate becomes effective and efficient (Allen and Meyer,1990; Sawitri, Suswati, and Huda, 2016).

Furthermore, it can be stated that organizational commitment in the world of education is a conscious effort without coercion and desires to be part of an educational organization (Churiyah, 2011), (Chaudhry and Joshi, 2017). There are some aspects of commitment, among others: a teacher who has high organizational commitment to the organization of the school where he serves, does not want to leave the school, because he feels that the goals of the organization are following his goals. Colquitt and Wesson (2009) also suggested that commitment can be influenced by: 1) organizational mechanisms; 2) group mechanisms; 3) individual characteristics; and 4) individual mechanisms. The leadership factor is part of the individual character factor which directly plays a role in organizational commitment. 
Based on this statement, the researcher wants to find out whether there is an influence of transformational leadership and job satisfaction on organizational commitment. The research is located at State Vocational School in Rejang Lebong Regency. The purpose of this study was to determine how much influence the transformational leadership of school principals and job satisfaction on the organizational commitment of vocational school teachers in Rejang Lebong Regency.

This research is expected to be useful for principals and teachers in order to know the critical determinants of the success of the principal's transformational leadership style and job satisfaction with organizational commitment.

\section{RESEARCH METHOD}

The method used was quantitative research with a descriptive approach. This method explains the results of calculations with regression techniques as an analysis tool. The population in this study was 106 teachers with 84 teachers as sample. Data collection techniques in this study used questionnaires, interviews and observations.

\section{RESULTS AND DISCUSSION}

Based on the results of the data analysis of Principal Transformational Leadership, Job Satisfaction and Organizational Commitment, research findings stated that there was a positive and simultaneous influence between the Principal Transformational Leadership and Job Satisfaction on Organizational Commitment. This influence is shown by the coefficient value of 0.706 with an effect of 0.498 or $49.8 \%$ in the form of positive linear regression equation is $\mathrm{Y}=23.88+0.42 \mathrm{X} 1+0.31 \mathrm{X} 2$. The same thing was stated by the theory of Colquitt and Wasson (2009) which emphasizing that organizational commitment is influenced by four general factors, namely: 1) organizational mechanisms, (2) group mechanisms, (3) individual's characteristics (individual character), and (4) individual mechanisms. These general factors are then broken down in detail and produce specific factors which include organizational culture, organizational structure, and leadership behavior, leadership influence, group processes, group character, personality, cultural values, job satisfaction, stress, motivation, values ethics, learning process and decision-making process. A person's organizational commitment depends on the factors mentioned above. The same thing was also stated by Bass (1997) regarding transformational leadership indicators, one of which includes Idealized Influence (Charisma), which is the leader displays confidence, emphasizes trust, takes on difficult issues, presents their most important values, and emphasizes the importance of goals, commitment and ethical consequences of decisions. Such leaders are admired as role models of pride, loyalty, trust and harmony around common goals. Thus, based on research findings that strengthened by the theoretical study of the experts regarding the effect of Principal Transformational Leadership and Job Satisfaction on Teacher Organizational Commitment has been verified.

\section{CONCLUSION}

The Principal Transformational Leadership Style and Job Satisfaction affect the Organizational Commitment of State Vocational School Teachers in Rejang Lebong Regency with a coefficient value of 0.706 and an effect of 0.498 or $49.8 \%$ in the positive linear form with the regression equation $\mathrm{Y}^{\wedge}=$ $23.88+0.42 \mathrm{X} 1+0.31 \mathrm{X} 2$, So, it can be conclude that the better of the Transformational Leadership Style of the School Principals and Job Satisfaction, the better the Commitment Organizations of Rejang Lebong District Vocational Teachers.

Based on the results of the study, suggestions are given to teachers to increase the organizational commitment, they should support the principal's decisions has to do with their assignments or work at school. Another thing that teachers need to do is participate in building a conducive work environment so that, it will support the achievement and success of the tasks given by the school principal. In addition, as a teacher, they need high motivation to improve their competence in working as a teacher in school. Thus, efforts to increase teacher organization commitment can be optimized and run as expected. 


\section{REFERENCES}

Allen, N. J., \& Meyer, J. P. (1990). The measurement and antecedents of affective, continuance and normative commitment to the organization. Journal of occupational psychology, 63(1), 1-18.

Bass, B. M. (1997). Does the transactional-transformational leadership paradigm transcend organizational and national boundaries? American psychologist, 52(2), 130.

Chaudhry, S., \& Joshi, C. (2017). Transformational leadership, HR practices and affective commitment to change: A theoretical perspective. Journal of Organization and Human Behaviour, 6(3), 37.

Churiyah, M. (2011). Pengaruh konflik peran, kelelahan emosional terhadap kepuasan kerja dan komitmen organisasi. Jurnal Ekonomi Bisnis, 16(2), 145-154.

Colquitt, L., \& Wesson, O. B. (2009). Improving Performance and Commitment in The Workplace. Florida: McGraw-Hill Irwin, 2.

Mullins, L. J. (2007). Management and organisational behaviour. Pearson education.

Purba, D. E., \& Seniati, A. N. L. (2010). Pengaruh Kepribadian Dan Komitmen Organisasi Terhadap Organizational Citizenzhip Behavior. Hubs-Asia, 10(1).

Robbins, S. P., \& Judge, T. A. (2006). Perilaku organisasi. Edisi kesepuluh. Jakarta: PT Indeks Kelompok Gramedia.

Sawitri, D., Suswati, E., \& Huda, K. (2016). The Impact of Job Satisfaction, Organization Commitment, Organization Citizenship Behavior On Employees' performance. International Journal of Organizational Innovation, 9(2).

Waworuntu, B. (2016). Perilaku Organisasi: Beberapa Model dan Submodel. Yayasan Pustaka Obor Indonesia. 